\title{
Variation pattern in production traits of broiler strains reared in a humid tropical environment \\ $*^{1}$ Obike, O. M., 'Obi, O. C., ${ }^{2}$ Onunkwo, D. N. and ${ }^{1}$ Aso, R. N. \\ ${ }^{l}$ Department of Animal Breeding and Physiology, Michael Okpara University of Agriculture, Umudike, Abia State, Nigeria.

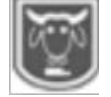 \\ ${ }^{2}$ Department of Animal Nutrition and Forage Science, Michael Okpara University of Agriculture, Umudike, Abia State, Nigeria. \\ Abstract \\ *Corresponding author: uceemer@yahoo.com
}

The study evaluated the effect of strain on productive traits of three broiler chickens. A total of 144 broilers, 48 each of Hubbard, Marshall and Ross were used for the experiment which lasted 8 weeks. The birds were reared in separate deep litter pens with each strain replicated into 4 having 12 birds per replicate. Data were generated on body weight and linear body parameters (body length $-B L$, keel length $-K L$, shank length $-S L$, wing length $-W L$, breast width $-B S W$, thigh length $-T L$ and drumstick length $-D L)$ at 2 weeks interval from the $2^{\text {nd }}$ week, growth performance, carcass and economics of production indices. Data were analyzed using the general linear model procedure of SPSS package. Results obtained showed significant $(p<0.05)$ differences among the strains for the various parameters studied. The Marshall strain was significantly $(p<0.05)$ superior in final body weight $(1861.14 \mathrm{~g})$ followed by Ross (1714.44 g) while the least in body size was Hubbard (1432.45 g). Daily weight gain ( $g /$ bird/day) and FCR were significantly $(p<0.05)$ better in Marshall and Ross compared to Hubbard. Marshall and Ross strain had significantly $(p<0.05)$ heavier body weights and longer bodies in week 2 -8; longer keels (week 6 and 8), thighs (week 2 and 6) and drumsticks (weeks 2, 6 and 8). Hubbard and Marshall showed statistically $(p<0.05)$ higher mean values for BSW than Ross in weeks 2 and 4. For the carcass traits, Marshall broiler also showed superiority ( $p<0.05$ ) over Ross and Hubbard in live weight 1818.75 vs 1653.13, $1500.00 \mathrm{~g}$ ), defeathered weight (1643.75 vs 1487.50, $1375.00 \mathrm{~g})$, dressed weight (1359.39 vs 1280.00,

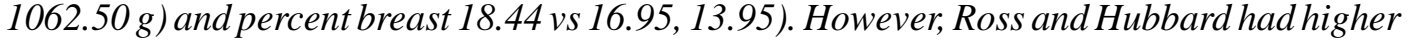
( $p<0.05)$ means for shank proportion than for Marshall. Results of the cost-benefit indices revealed that the Marshall strain significantly ( $p<0.05)$ generated more revenue (\$1460.91/bird) and gross profit (\$666.52/bird) compared to its counterpart strains. Marshall could therefore be recommended to farmers in our study area as a choice strain with faster growth and superior carcass yield for maximum economic return.

Keywords: Variation, production traits, broiler, strain

\section{Introduction}

Consumer demand for chicken products has been on the rise in both foreign and local markets due to rapid increase in world population and the perceived health benefit of chicken meat.

Ojedapo et al. (2015) reported that statistics have shown that the demand for poultry products is on a geometric increase, and that chicken meat costs less than other meats; thus its market share is also on the increase. The authors also noted that demand for poultry products is equally high in Nigeria, and that the current rate of production is extremely low and inadequate to meet the demand.

On this, the Nigerian poultry industry over the years has experienced the introduction of different broiler strains into the country. The evaluation of the different commercial 
broiler strains as well as management techniques is therefore important in order to improve production efficiency. The knowledge of variability of genotype/strain of chicken accompanied by manipulation of their production system will translate into desirable carcass and meat quality characteristics, which is paramount for consumers in making purchasing decisions (Assan, 2015). Fanatico et al. (2007) noted genotype as an important factor in any chicken production system since it influences carcass and meat quality. Ojedapo et al. (2008) and Amao et al. (2009) stressed on the different commercial broiler strains with regards to breeding management and growth traits. Razuki et al. (2011) reported significant strain differences in body weight at different ages among broiler chickens.

A c cording to FAO (2012), growth/quantitative traits are generally the dimensions of different body parts and live weight which are directly related to production parameters. It then means that growth in animals is evaluated from the component parts and body weight of the animal. These traits (body length, shank length, breast width, keel length, wing length etc and body weight) may vary with genotype and sex and may also be influenced by the method of data analysis (Assan, 2015). Some authors inferred that characterization of animal genetic resources depends on the knowledge of the variation of growth traits (Aberra and Tegene, 2011; Ferra et al., 2010), which are also important production and selection criteria (Bene et al., 2007).

In Nigeria today, broiler production is one of the most popular enterprises for both small and medium scale farmers in the rural and urban areas. There arises the need to continually evaluate and determine the performance of the different broiler strains since performance evaluation forms the initial step in any meaningful genetic improvement programmes as well as identification of strains most suited for particular environment for increased production output.

The objective of this study was therefore to estimate the production traits (body weight, linear body, carcass and economics of production) of three broiler strains (Marshal, Hubbard and Ross) reared in a humid tropical environment.

\section{Materials and methods}

This research was conducted at the Poultry unit of the Teaching and Research farm of Michael Okpara University of Agriculture, Umudike located on latitude $05^{\circ} 29 \mathrm{~N}$ and longitude $07^{\circ} 33 \mathrm{E}$. Umudike is on an elevation of $122 \mathrm{~m}$ above sea level and located in tropical rain-forest zone of Nigeria, which is characterized by annual rainfall of about $2177 \mathrm{~mm}$; monthly ambient temperature ranges of $22-33^{\circ} \mathrm{C}$ and relative humidity of 50-95\% depending on the season.

\section{Experimental animals and management}

A total of 150 day-old broiler chicks (Marshal, Hubbard and Ross) were purchased from a reputable hatchery in Ibadan, Nigeria. Two weeks to the arrival of the birds, the brooder house was washed, disinfected and allowed to dry. On arrival, anti-stress preparations were administered to enable the chicks recover from transportation stress. The birds were brooded for 2 weeks and were transferred to deep litter pens afterwards. Antibiotics and anticoccidial drugs were administered at relevant periods. All routine vaccination and management procedures were strictly followed. Wood shavings were used as litter materials. Feed and water were given to the birds ad libitum. The experiment lasted for 8 weeks. 


\section{Obike, Obi, Onunkwo and Aso}

After brooding, each of the strain was replicated into four with 12 birds per replicate. Measurements were taken on the following parameters:

\section{Growth performance traits}

Initial weight: weight of the birds at the beginning of the experiment taken with the aid of a weighing scale

Final weight: weight of the birds at 8 weeks taken with the aid of a weighing scale.

Daily weight gain:

Final weight - initial weight

Number of birds/56 days

Average daily feed intake:

Quantity of feed given $(\mathrm{g})$ - leftover

Number of birds/56 days

Feed conversion ratio:

Average daily feed intake (g/bird)

Average daily weight gain (g/bird)

Linear body parameters

Body length:distance between the base of the neck and pygostyle.

Keel length:length of the cartilaginous keel bone, from the $\mathrm{v}$-joint to the end of the sternum.

Shank length: beginning of hock joint to the last ring before the tarsal or meta-tarsal digit.

Wing length: distance from the shoulder joint to the extremity of the terminal phalange.

Breast width:region of the largest breast expansion when positioned ventrally.

Thigh length:beginning of the fibula to the hock joint.

Drumstick length: length of femur bone.

\section{Carcass evaluation}

At the end of the experiment, two birds per replicate were randomly selected for carcass yield. The birds were deprived of feed over night to avoid gut fill, weighed and killed by slitting the jugular vein. The birds were defeathered after immersing them in hot water, plucked and eviscerated. The dressed birds were weighed to obtain dressed weight before cutting into parts - breast, shank, wing, thigh, drumstick, neck and back, which were weighed separately according to Scott et al. (1969). Dressed weight, slaughtered weight, cut parts and internal organs were expressed as percent of live weight.

\section{Economics of production}

Cost of production analysis of each strain was determined at the end of the finisher phase to compare the profitability of the strains. The parameters measured were:

Cost $/ \mathrm{kg}$ feed $=$ proportion of each ingredient in the diet $x$ cost $/ \mathrm{kg}$ of ingredient

Table 1: Growth performance parameters of Hubbard, Marshall and Ross broiler strains

\begin{tabular}{lccc}
\hline & \multicolumn{3}{c}{ Strains of chicken } \\
\cline { 2 - 4 } Parameter & Hubbard & Marshall & Ross \\
\hline Initial weight $(\mathrm{g})$ & $38.25 \pm 2.04$ & $35.00 \pm 2.03$ & $37.50 \pm 2.04$ \\
Final weight $(\mathrm{g})$ & $1432.45 \pm 2.00^{\mathrm{c}}$ & $1861.14 \pm 1.08^{\mathrm{a}}$ & $1714.44 \pm 2.01^{\mathrm{b}}$ \\
Daily weight gain g/bird/day & $24.90 \pm 0.00^{\mathrm{b}}$ & $32.61 \pm 0.00^{\mathrm{a}}$ & $31.73 \pm 0.00^{\mathrm{a}}$ \\
Daily feed intake g/bird/day & $84.40 \pm 2.02$ & $88.70 \pm 2.00$ & $86.90 \pm 2.04$ \\
FCR & $3.39 \pm 0.07^{\mathrm{b}}$ & $2.76 \pm 0.05^{\mathrm{a}}$ & $2.74 \pm 0.05^{\mathrm{a}}$ \\
\hline abc $=$ means along each column differ significantly $(\mathbf{P}<\mathbf{0 . 0 5}) . \mathbf{S E}=$ standard error of mean
\end{tabular}

Body weight and linear body parameters of Hubbard, Marshal and Ross strains

The least square means plus their standard errors of body weight and linear body measurements at $2-8$ weeks of age of Hubbard, Marshal and Ross are presented in Table 2. Significant $(\mathrm{p}<0.05)$ differences existed among the strains in body weight and linear traits except for SL and WL. Researchers have reported substantial effect of genotype on body weight and linear body traits (Olawumi et al., 2012; Yahaya et al., 
Variation pattern in production traits of broiler strains reared in a humid tropical environment

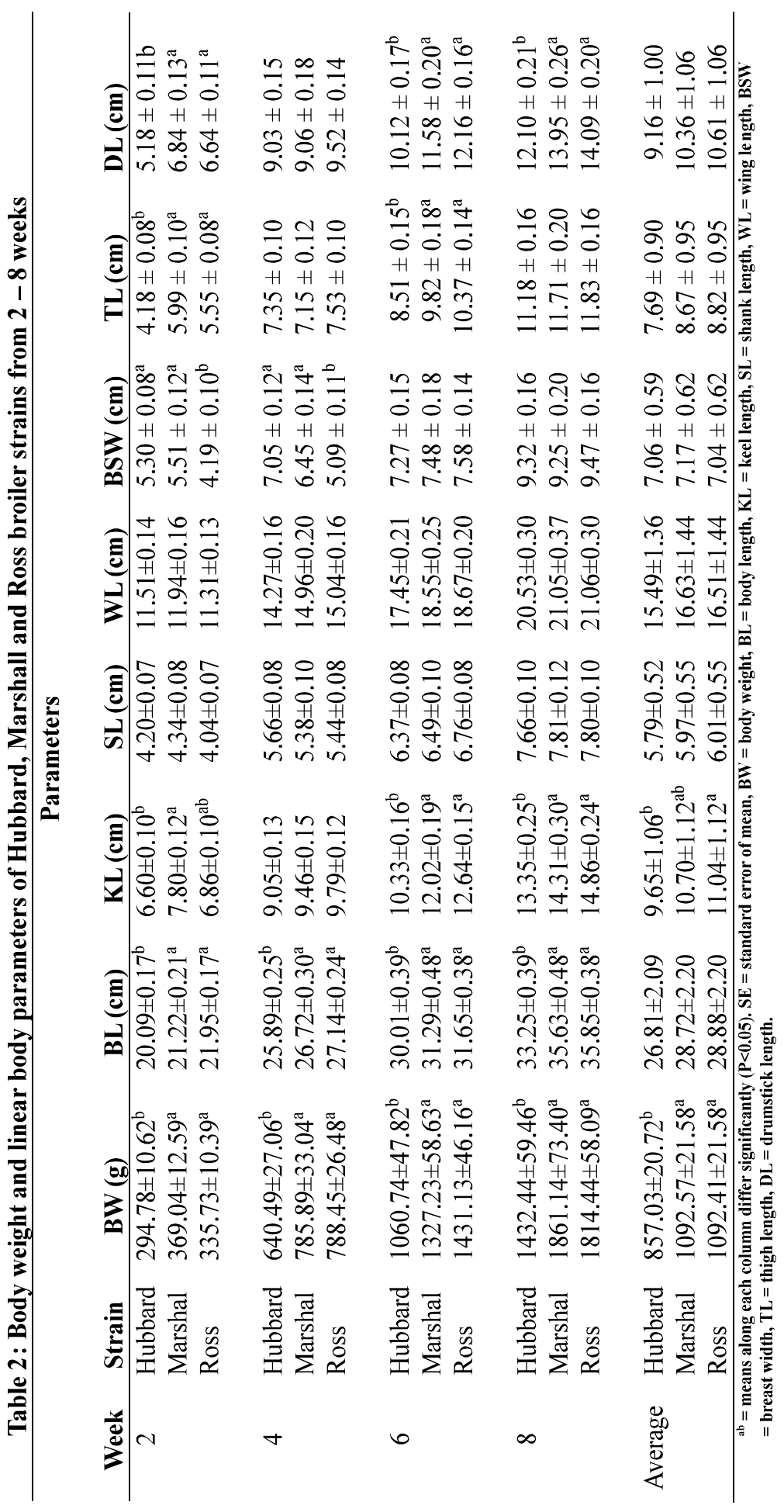




\section{Obike, Obi, Onunkwo and Aso}

2012). Marshal and Ross strains were significantly similar $(\mathrm{p}>0.05)$ and differed $(p<0.05)$ from Hubbard in body weight at all the ages. The values recorded for body weight among the strains increased progressively with age of the birds. Differences in body weight among broiler strains established in this study have previously been reported (Razuki et al., 2011; Taha et al., 2011; Obike et al., 2015; 2016). Udeh et al. (2015) reported that the body weights of Arbor Acer and Marshal were significantly $(\mathrm{p}<0.05)$ superior to that of Ross broilers at weeks 1, 2, 3 and 4 . However, the researchers noted similarity of body weight in weeks $5-7$ for Marshal and Ross. At 8 weeks of age, Amao et al. (2011) noted significantly $(\mathrm{p}<0.05)$ heavier weight for Ross compared to Marshal, which contradicts our finding. Ojedapo (2013) gave mean values for body weight which ranged from $374.78 \mathrm{~g}-1981.34 \mathrm{~g}$ at week $2-8$ in Marshal. This is slightly higher than the mean values (369 g $1092.57 \mathrm{~g}$ ) observed in this study for Marshal.

Marshal and Ross were also significantly $(\mathrm{p}<0.05)$ superior to Hubbard in BL (week 2, 4, 6 and 8), KL (week 6 and 8), TL (week 2 and 6) and DL (week 2, 6 and 8). For BSW, Hubbard and Marshal had wider $(\mathrm{p}<0.05)$ breast width proportion than the Ross strain. Significant differences in linear body measurements have also been reported (Olawumi et al., 2012; Yahaya et al., 2012). Obike et al. (2016) found that Arbor Acer strain had significantly $(p<0.05)$ longer body length, shank length, keel length, wing length, drumstick length and wider chest circumference in relation to the Cobb strain. Significant strain effect on breast girth and shank length was reported by Ajayi and Ejiofor (2009). As observed with body weight, the linear body traits measured increased progressively with age in this study. Pingel et al. (1990) reported that age was the major determinant of growth and physiological development in chicks. Obike et al. (2016) also observed increase in body traits of broilers as they advanced in age. The results obtained in this study implied existence of genetic differences in growth rates among the three commercial strains. It is in consonance with earlier report of differences in growth pattern within species

(Deeb and Lamont, 2002). The higher performance of Marshal and Ross suggests that the strains might be most suitable to rear in our study area.

\section{Carcass and economics of production indices}

Table 3 presents the means and standard errors of carcass traits of the broiler strains evaluated. Significant $(p<0.05)$ strain effects were observed in live weight, defeathered weight, dressed weight, breast, wing and shank. Marshall recorded superior and higher mean values in live weight (1818.75 g), defeathered weight (1643.75 g), dressed weight (1359.39 g) and percent breast (18.44) than Ross and Hubbard but was similar in dressed weight and percent wing with Ross. Hubbard and Ross strain had significantly $(\mathrm{p}<0.05)$ higher mean value for percent shank in comparison with the mean recorded for the Marshal strain. Strain effect has been previously reported to influence carcass characteristics (Musa et al., 2006; Ojedapo et al., 2008). Mendes et al. (1994) observed significant strain effect on carcass yield and percentage of breast meat in four broiler strains. Olawumi and Fagbuaro (2011) evaluated the productive performance of Marshall, Arbor Acer and Hubbard broilers, and reported that the Marshall genotype was superior to Arbor Acer and Hubbard in live weight, carcass weight, dressed weight, eviscerated weight, breast muscle weight, back muscle weight, 
thigh muscle weight, drumstick and heart weight. This report is in agreement with our findings except for drumstick, thigh and back which did not differ statistically among the broiler strains used in our study. On the contrary, Ojedapo et al. (2015) investigated carcass traits of broiler strains
(Cobb and Marshall) slaughtered at 4, 6 and 8 weeks respectively and reported that the Cobb significantly $(\mathrm{p}<0.05)$ outperformed the Marshall in all the carcass and visceral organ characteristics assessed. These results confirm that genetic potential is a major determinant of carcass yield.

Table 3: Carcass characteristics of Hubbard, Marshall and Ross broiler strains

\begin{tabular}{lccc}
\hline & \multicolumn{3}{c}{ Strains of chicken } \\
\cline { 2 - 4 } Parameter & Hubbard & Marshall & Ross \\
\hline Live weight $(\mathrm{g})$ & $1500.00 \pm 102.68^{\mathrm{c}}$ & $1818.75 \pm 125.76^{\mathrm{a}}$ & $1653.13 \pm 102.68^{\mathrm{b}}$ \\
Defeathered weight $(\mathrm{g})$ & $1375.00 \pm 96.79^{\mathrm{b}}$ & $1643.75 \pm 118.54^{\mathrm{a}}$ & $1487.50 \pm 96.79^{\mathrm{b}}$ \\
Dressed weight $(\mathrm{g})$ & $1062.50 \pm 105.93^{\mathrm{b}}$ & $1359.38 \pm 129.74^{\mathrm{a}}$ & $12800.00 \pm 105.93^{\mathrm{b}}$ \\
Breast $(\%)$ & $13.95 \pm 1.19^{\mathrm{b}}$ & $18.44 \pm 1.19^{\mathrm{a}}$ & $16.92 \pm 1.46^{\mathrm{b}}$ \\
Wing (\%) & $12.80 \pm 0.59^{\mathrm{a}}$ & $10.25 \pm 0.72^{\mathrm{b}}$ & $10.37 \pm 0.59^{\mathrm{b}}$ \\
Drumstick (\%) & $10.16 \pm 0.51$ & $11.73 \pm 0.63$ & $11.66 \pm 0.51$ \\
Shank (\%) & $5.35 \pm 0.27^{\mathrm{a}}$ & $4.43 \pm 0.33^{\mathrm{b}}$ & $5.59 \pm 0.27^{\mathrm{a}}$ \\
Thigh (\%) & $12.44 \pm 0.81$ & $11.84 \pm 0.99$ & $12.69 \pm 0.81$ \\
Neck (\%) & $7.31 \pm 0.49$ & $5.79 \pm 0.60$ & $7.08 \pm 0.49$ \\
Back (\%) & $14.72 \pm 0.86$ & $14.23 \pm 1.05$ & $15.53 \pm 0.86$
\end{tabular}

The economics of production analysis of the three broiler strains is as indicated in Table 4. Significant differences $(\mathrm{p}<0.05)$ were also observed among the strains for the cost-benefit traits analyzed. The cost of feed consumed per bird as well as cost per unit weight gain was less for Marshall and Ross compared to Hubbard. However, the Marshall strain generated more revenue (N1460.91/bird) and gross profit (N666.52/bird) followed by Ross ( $1321.55 /$ bird; $\$ 538.25 /$ bird). Hubbard had the least values for revenue
(N1115.36/bird) and gross margin (\$347.46). Similar results indicating significant variations in cost of production analysis of broiler strains have been reported (Yakubu et al., 2010; Obike et al., 2015; 2016). Iqbal et al. (2012) reported that the overall performance of Hubbard strain seemed better as the birds gained more body weight, gave better FCR, least mortality and least cost per $\mathrm{kg}$ live broiler produced as compared to Ross, Arbor Acer and Hybro PN strains. Our result indicates that rearing Marshall could be more profitable to farmers in our environment.

Table 4: Economics of production of Hubbard, Marshall and Ross broiler strains

\begin{tabular}{lcccc}
\hline & \multicolumn{3}{c}{ Strains of chicken } \\
\cline { 2 - 4 } Parameter & Hubbard & Marshall & \multicolumn{1}{c}{ Ross } & \multicolumn{1}{c}{ SEM } \\
\hline Cost/kg feed (N) & 110.00 & 110.00 & 110.00 & 0.29 \\
Cost of feed consumed (N) & $546.39^{\mathrm{a}}$ & $519.90^{\mathrm{b}}$ & $525.30^{\mathrm{b}}$ & 3.84 \\
Feed cost/weight gain (N/bird) & $372.90^{\mathrm{a}}$ & $303.60^{\mathrm{b}}$ & $301.40^{\mathrm{b}}$ & 11.74 \\
Revenue (N/bird) & $1115.36^{\mathrm{c}}$ & $1460.91^{\mathrm{a}}$ & $1321.55^{\mathrm{b}}$ & 54.61 \\
Gross margin ( $/$ /bird) & $347.46^{\mathrm{c}}$ & $666.52^{\mathrm{a}}$ & $538.25^{\mathrm{b}}$ & 50.99 \\
\hline abc $=$ means along each column differ significantly $(\mathbf{P}<\mathbf{0 . 0 5}) \mathbf{S E M}=$ standard error of mean & &
\end{tabular}




\section{Conclusion}

It was revealed in this study that broiler strain showed significant influence on growth performance, growth rate, carcass characteristics and economics of production indices. Marshall recorded higher mean values and showed superiority over Ross and Hubbard in almost all the growth performance, carcass and economics of production traits measured. The Marshall strain also yielded more revenue and gross margin followed by the Ross. Marshall could be recommended to farmers in our study area as strain of choice with faster growth and superior carcass yield for maximum economic return.

\section{References}

Aberra, M. and Tegene, N. 2011. Phenotypic and morphological characterization of indigenous chicken population in southern region of Ethopia. Animal Genetic Resources, 49: 19-31.

Ajayi, F. O. and Ejiofor, O. 2009. Effect of genotype $\mathrm{x}$ sex interaction on growth and some development characteristics of Ross and Anak broiler strains in the high rainforest zone of Nigeria. Asian Journal of Poultry Science, 3: 51-56.

Amao, S. R., Akinokun, O., Ojedapo, L. O., Adedeji, T. A. and Sodeinde, F. G. 2009. Estimate of genetic variabilities of growth traits of two strains of starter broiler chickens reared in derived savanna environment of Nigeria. Proceeding of the $14^{\text {th }}$ Annual Conference of Animal Science Association of Nigeria, Lautech, Ogbomoso. Pp. 103-105.

Amao, S. R., Ojedapo, L. O. and Sosina, O. A. 2011. Evaluation of growth performance traits in three strains of broiler chickens reared in derived savannah environment of Nigeria. World Journal of Young Researchers, 1:28-30.

Assan, N. 2015. Genotype and sex influencing dressing percentage, carcass parameters and meat quality properties in indigenous chickens. Scientific Journal of Biological Sciences, 4:43-52.

Bene, S., Nagy, B., Nagy, L., Kiss, B., Polgar, J. P. and Szabo, F. 2007. Comparison of body measurements of beef cows of different breeds. Arch Tierz Dummerstorf, 50:363373.

Dairo, T. A., Oluwasola, T. A., Adesehanwa, A. O. K. and Oluyemi, J. A. 2009. Relationship between body measurement and body weight in Sahara and Nubien goat breeds. Proceeding of the $7^{\text {th }}$ International Conference on goats, France. Pp. 223-229.

Deeb, N. and Lamont, S. J. 2002. Genetic architecture of growth and body composition in unique chicken populations. Heredity, 93: 107-118.

Duncan, D. B. 1955. Multiple ranges and multiple F-test. Biometrics 11: 1-42.

Fanatico, A. C., Pillai, P. B., Emmert, J. L. and Owens, C. M. 2007. Meat quality of slow-and fast-growing chicken genotypes fed low-nutrient or standard diets and raised indoors or with outdoor access. Poultry Science, 86: 2245-2255.

FAO, 2012. Phenotypic characterization of animal genetic resources. FAO Animal Production and Health guidelines, (11) Rome.

Ferra, I. C., Oeslak, S. Filho, R. S., McManus, C., Martins, C. L. and Seneno, J. R. B. 2010. Weight and age at puberty and their correlations 
Variation pattern in production traits of broiler strains reared in a humid tropical environment

and morphometric measurements in crossbred Suffolk ewe lambs. Revista Brasileira de Zootecnia, 39: 134-141.

Iqbal, J., Mian, A. A., Ahmad, T., Hassan, S. and Khan, S. H. 2012. Comparative performance of different economic traits of four imported broiler strains under local conditions of Pakistan. Pakistan Journal of Agricultural Research, 25: 76-82.

Mendes, A. A., Garcia, E.A., Gonzales, E. and Politi, E. S. 1994. Effect of strain on yield in broiler. Poultry Abstract, 20: 103.

Musa, H .H., Chen, G. H., Wang, K. H., Li, B. C., Mekki, D. M., Shu, J. T. and Ju, H. P. 2006. Relation between serum cholesterol level, lipoprotein concentration and carcass characteristics in genetically lean and fat chicken breeds. Journal of Biological Sciences, 6: 530-533.

Obike, O. M., Orji, N. G., Okah, U. and Adedokun, O. O. 2015. Comparative evaluation of growth performance, carcas s characteristics and economics of production of Anak and Marshal broiler strains in a humid rainforest zone of Nigeria. The Nigerian Agricultural Journal, 46: 281-291.

Obike, O. M., Ukoha, O. A. and Emmanuel, F. H. 2016. Growth performance, linear measurement and cost-benefit of two strains of broiler chickens in a humid tropical environment. Nigerian Journal of Agriculture, Food and Environment, 12:90-94.

Ojedapo, L. O. 2013. Phenotypic correlation between the external and internal egg quality traits of Pharaoh quail reared in derived savannah zone of Nigeria. Journal of Biology, Agriculture and Healthcare, 3: 80-83.

Ojedapo, L. O., Akinokun, O., Adedeji, T. A., Olayeni, T. B., Ameen, S. A. and Amao, S. R. 2008. Effect of strain and sex on carcass characteristics of three commercial broilers reared in deep litter system in derived savanna area of Nigeria. World Journal Agricultural Science, 4: 487-491.

Ojedapo, L. O., Amao, S. R. and Ogunsola, O. O. 2015. Variation of meat-type chickens in relation to genotypes and age of slaughter on carcass indices. Journal of new Sciences, 14: 473-478.

Olawumi, S. O. and Fagbuaro, S. S. 2011. Production performance of three commercial broiler genotypes reared in derived savannah zone of Nigeria. International Journal of Agricultural Research, 6:798-804.

Olawumi, S. O., Ogunlade, T. and Fajemilehin, S. 2012. Production traits of broiler chicken strains fed ad libitum and raised on deep litter system in the humid tropics. Animal Research International, 9: 15291536.

Pingel, H., Schneider, K. H. and Birla, M. 1990. Factors affecting meat quality in broilers. Tierzucht, 44: 300-301.

Razuki, W. M., Mukhlis, S. A., Jasim, F. H. and Hamad, R. F. 2011. Productive performance of four broiler strains reared under high ambient temperatures. International Journal of Poultry Science, 10: 87-92.

Scott, M. L., Nesheim, M. C. and Young, R. H. 1969. Nutrition of chicken. Scott and Associate's Publishers, 
Ithaca, New York.

SPSS, 2011. Statistical procedure for social sciences and facilities for release. Mcgrow-Hill Company, New York.

Taha, A. E., Abd El-Ghany, F. A. and Sharaf, M. M. 2010. Strain and sex effects on productive and slaughter performance of developed local Egyptian and Canadian chicken strains. Egyptian Poultry Science, 30: 1059-1072.

Udeh, I., Ezebor, P. N. and Akporahuarho, P. O. 2015. Growth performance and carcass yield of three commercial strains of broiler chickens raised in a tropical environment. Journal of Biology, Agriculture and Healthcare, 5: 62-67.
Yahaya, H. K., Brahim, H. and AbdulSalam, S. 2012. Comparative study of the body weight and body conformation of two broiler strains under the samedietry condition. International Journal of Animal and Veterinary Advances, 4: 195-197.

Yakubu, A., Ayoade, J. A. and Dahiru, Y. M. 2010. Effects of genotype and population density performance, carcass characteristics and costbenefits of broiler chickens in north central Nigeria. Tropical Animal Health and Production, 42: 719727.

Received: $10^{\text {th }}$ July, 2017

Accepted: $9^{\text {th }}$ December, 2017 